\title{
Features of active medium for wide-band spectrum tuned dye laser
}

\author{
V.V.Maslov \\ A.Usikov Institute of Radiophysics and Electronics, National Academy of
Sciences of Ukraine, 12 Acad. Proskury St., 61085 Kharkiv, Ukraine
}

Received May 5, 2014

Spectral, fluorescent and lasing characteristics of mixtures of three couples of the laser dyes have been studied with the purpose of broadening the laser tunable range. We have used the dyes those have the absorption spectra in the close spectral regions near wavelength of pumping, but their fluorescence spectra have essentially different Stokes shift. As a result, the fluorescent band of these dye mixtures expands. It is noted the substantial condition for these mixtures of the dyes is the absence of nonradiating losses which may be appeared under interaction of the dye molecules or under interaction of them with the solvent molecules. The continuous tuning of laser radiation more than $100 \mathrm{~nm}$ : throughout the yellow and red ranges from $572 \mathrm{~nm}$ to $687 \mathrm{~nm}$ has been fulfilled under laser pumping with only one solution of Rh6G and DCM mixture in DMSO.

С целью расширения диапазона перестройки спектра излучения лазера на красителях исследованы спектрально-флуоресцентные и лазерные характеристики трёх пар красителей, которые имеет спектры поглощения в соседних областях вблизи длины волны накачки, а их спектры флуоресценции имеют существенно различающийся Стоксов сдвиг. В результате полоса флуоресценции смеси красителей расширяется. Отмечается важное условие для такой смеси красителей - отсутствие в ней безызлучательных потерь, которые могут возникать как при взаимном влиянии молекул красителей, так и при взаимодействии их с молекулами растворителя. На одной смеси красителей Rh6G и DCM в диметилсульфоксиде при лазерном возбуждении осуществлена непрерывная перестройка спектра генерации в диапазоне более 100 нм, перекрывающем желтую и красную области (572-687 нм).

Характеристики активного середовища лазера на барвниках з широкодіапазонним перестроюванням спектра випромінювання. В.В.Маслов.

3 метою розширення діапазону перестроювання спектра випромінювання лазера на барвниках досліджено спектрально-флуоресцентні та лазерні характеристики сумішей трьох пар барвників, які мають спектри поглинання у сусідніх областях поблизу довжини хвилі накачування, а їх спектри флуоресценції - суттєво відмінний Стоксів зсув. Результатом цього є розширення смуги флуоресценції суміші барвників. Відзначається важлива умова для такої суміші барвників - відсутність у ній безвипромінювальних втрат, які можуть з'являтися як при взаємному впливі молекул барвників, так і при взаємодії їх з молекулами розчинника. На одній суміші барвників Rh6G та DCM у диметилсульфоксиді при лазерному збудженні здійснено безперервне перестроювання спектра генерації у діапазоні більшим, ніж 100 нм, який перекриває жовту та червону області (572-687 нм).

\section{Introduction}

Dye lasers (DL), the universal generators of continuously tuned optical radiation, are being actively investigated and developed with the purpose of their upgrading for manifold new practical applications [1,2]. Furthermore molecules of laser dyes are 
Table 1. Spectral and laser characteristics" of the dyes in methanol

\begin{tabular}{|c|c|c|c|c|c|c|}
\hline & $\lambda_{m}^{a}, \mathrm{~nm}$ & $\begin{array}{c}\varepsilon_{m} \cdot 10^{-3}, \\
1 \cdot \mathrm{mol}^{-1} \cdot \mathrm{cm}^{-1}\end{array}$ & $\lambda_{m}^{f}, \mathrm{~nm}$ & $q^{f}$ & $\lambda_{\text {lamp }}, \mathrm{nm}$ & $\lambda_{\text {las }}, \mathrm{nm}$ \\
\hline 483 & 58.0 & 521 & 0.84 & 557 & 536 \\
\hline
\end{tabular}

$* \lambda^{a}{ }_{m}-$ maximum of long-wavelength absorption band; $\varepsilon_{m}-$ molar decadic extinction coefficient at $\lambda_{m}^{a} ; \lambda_{m}^{f}$ - wavelength of fluorescence maximum; $q^{f}-$ fluorescence quantum yield; $\lambda_{\text {lamp }}-$ central wavelength of lasing spectrum under lamp pumping; $\lambda_{\text {las }}$ - central wavelength of lasing spectrum under laser pumping $\lambda_{\text {pump }}=470 \mathrm{~nm}$.

used as activating dopant or converter of light signal when new elements and devices of photonics are developed [3,4]. So authors of [3] experimentally demonstrated at the room-temperature lasing of opal photonic crystal made of rhodamine-B doped polystyrene colloids. The auxiliary lasers and their harmonics radiating in the green region of spectrum are often used for excitation of these lasers and devices. In addition the problem of broadening of emission spectral range for conventional DL and new elements of laser photonics [4] continues to be topical.

Earlier we have studied active media on the basis of laser dyes and their mixtures those permitted to tune narrowband radiation of the DL throughout the red and near IR regions of spectrum under pumping with green monochromatic radiation [5]. The aim of the present exploration was broadening of the laser tuning range in the spectrum shortwave region, viz in its yellow segment.

\section{Experimental}

At first we examined two laser dyes those were studied by us earlier [6]. These dyes were synthesized in V.Karazin Kharkiv National University and had efficient lasing in the yellow-green region of the spectrum $\lambda_{\text {em }}=550-560 \mathrm{~nm}$ under lamp excitation. Their absorption spectra maxima $\left(\lambda_{a} \approx 483 \mathrm{~nm}\right)$ were close to the same value of DCM dye [5], and therefore together with it the synthesized dyes may compose the laser medium with widened region of the laser spectrum tuning. Structure formulas of selected dyes and main spectral and lasing characteristics of their methanol solutions in the DL with non-selective cavity (NSC) under flashlamp [6] and laser pumping are given in the Table 1. Characteristics of the DCM dye (ALDRICH) in methanol [5] are adduced in the lower row of the table.

Examinations of methanol solutions of GD1 and GD2 dyes in the DL NSC under laser pumping were carried out in setup described earlier [5, 7]. Excitation of this laser was produced by transverse scheme with radiation of the DL with flashlamp pumping (FLP) on ethanol solution of coumarin $\mathrm{C} 1$ of $\sim 3.7 \cdot 10^{-4} \mathrm{~mol} / 1$ concentration. Central wavelength of pumping was $\lambda_{\text {pump }}=$ $470 \mathrm{~nm}$, and half-width of its spectrum at 0.1 level $-\Delta \lambda_{0.1}=2 \mathrm{~nm}$. Laser energy of the studied dyes and their mixtures in the DL NSC and energy of the DL FLP radiation were monitored with measurers of IMO-2N type. Laser spectra were registered by an UF-90 camera and photographic apparatus of EOS 400D DIGITAL type.

Measure of tuning range of the studied solutions was fulfilled in a laser [8] with resonator formed by wideband dielectric mirror with $R \approx 99 \%$ and diffraction grating of 1200 lines $/ \mathrm{mm}$. Output of the laser radiation was realized via zeroth order of the diffraction grating. Pumping was produced transversely by flashlamp-pumped dye laser (FLPDL) on ethanol solution of coumarin C314. The pump radiation $\left(\lambda_{\text {pump }}=508 \mathrm{~nm}\right)$ was focused on lateral surface of the cell along 
its axis by cylindrical lens with $F=$ $110 \mathrm{~mm}$.

Absorption spectra of some studied laser dye solutions were written with a Lambda 35 spectro-photometer (Perkin-Elmer, USA) and fluorescence ones with a FluoroMax-4 spectrofluorimeter (Horiba Jobin Yuon, USA). Solutions with optical density at maximum - $D_{\max } \approx 1.0$ were prepared for measuring of absorption characteristics, and with optical density at extinction wavelength $-D_{e x} \approx 0.02 \pm 0.01$ for fluorescent ones.

\section{Results and discussion}

The fulfilled measures showed that energy efficiency of the selected dyes is similar to ones of solution of DCM in dimethylsulfoxide (DMSO). The last has maximal output laser energy under microsecond pumping of the DL just in this solvent [5]. It is connected with possibility of DCM molecules in weakly polar solvents methanol, ethanol, et al. to generate TICT forms [9] in excited states. These forms increase probability of non-radiating transitions and result in fluorescence quenching. It was shown [10] that the quantum yield of DCM in solution increased when methanol was replaced by acetonitrile (AcN) and achieved the maximum in DMSO, which has a high polarity. Within DMSO $92 \%$ of DCM dye molecules exist in coplanar transform [10] and as a result its quantum yield grows.

Energy and spectral parameters of lasing for the solutions of GD1 and GD2 dyes in the DL NSC were measured in $A C N$ and DMSO too. Note that laser spectrum of these dyes shifted to the long-wavelength side more than $10 \mathrm{~nm}$ when methanol was changed by AcN and about $20 \mathrm{~nm}$ - by DMSO. At the same time their laser energy in $\mathrm{AcN}$ was remained the same as for methanol solutions, but it decreased essentially for DMSO. Nevertheless the solutions of the mixtures GD1 + DCM and GD2 + DCM were tested in the NSC. The examinations showed that solutions of the green dyes generated laser radiation in the green region of the spectrum with a small long-wavelength shift $(\leq 15 \mathrm{~nm})$ relative to the single-component solution when additions of DCM in the solution were small $\left(C_{\mathrm{DCM}}<100 \mu \mathrm{mol} / 1\right)$. In this case the output laser energy decreased about in a half. When concentration of DCM dye in the mixture $C_{\mathrm{DCM}} \geq 100 \mu \mathrm{mol} / 1 \mathrm{its}$ laser spectrum "jumped" to the red range

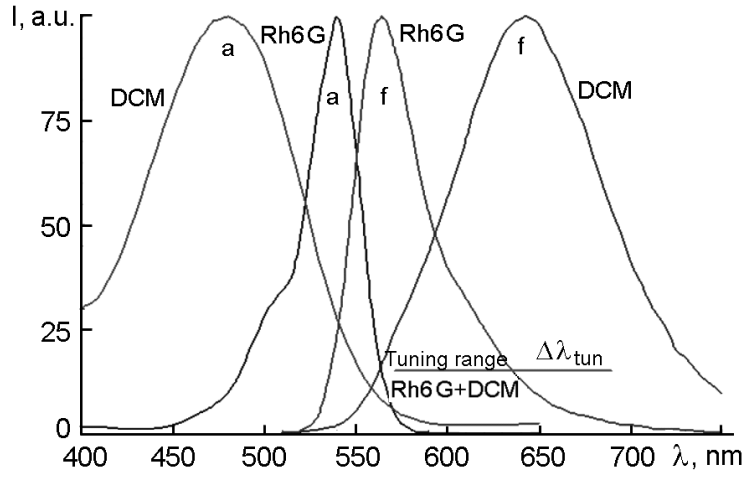

Fig. 1. Absorption (a) and fluorescence (f) spectra of Rh6G and DCM dyes in DMSO, and tuning range $\left(\Delta \lambda_{t u n}\right)$ of lasing spectrum of their mixture in DMSO.

$\lambda_{\text {las }} \approx 655 \mathrm{~nm}$ - the one of lasing for single-component solution of DCM in DMSO.

Appreciable decrease of the laser energy of the green dyes when DCM was added in operating solution indicates increasing of losses in it. We conceive that it was most likely caused by the non-radiating transfer of energy of excited states of GD1 and GD2 dyes to the molecules of the DCM dye because fluorescence spectra of the firsts do not practically overlap with the absorption spectrum of the last one. At the same time, the gain factor in the red region under used pump levels does not achieve its threshold value because of low concentration of DCM in the operating solution $\left(C_{\mathrm{DCM}}<\right.$ $100 \mu \mathrm{mole} / \mathrm{l})$. Furthermore the optimal solvent DMSO for laser energy parameters of the DCM dye turned out was not optimal for GD1 and GD2. Thus the dye composition selected via the spectral-fluorescence characteristics for extension of tuning range to the yellow-green region was found to be unpromising.

We fulfilled a series of probations in the DL NSC with other laser dyes which are more short-wave than DCM such as Rhodamine 110 and Rhodamine 6G "DKE" ("For Quantum Electronics") and decided on Rhodamine 6G (Rh6G) in the issue of analyzing their laser spectral-energy characteristics. The measured absorption and fluorescence spectra of the Rh6G and DCM dyes in DMSO are shown in Fig. 1. Note that the spectrofluorimeter allowed to record corrected spectra taking into account the corrections for spectral sensibility of analyzing monochromator and photodetector. It was important [11] for finding fluorescence quantum yield $q$ of the dye solutions. The 
Table 2. Spectral characteristics* of Rh6G and DCM

\begin{tabular}{|c|c|c|c|c|c|c||}
\hline Dye/Solvent & $\lambda_{m}^{a}, \mathrm{~nm}$ & $\begin{array}{c}\varepsilon_{m} \cdot 10^{-3}, \\
1 \cdot \mathrm{mol}^{-1} \cdot \mathrm{cm}^{-1}\end{array}$ & $\lambda_{m}^{f}, \mathrm{~nm}$ & $q^{f}$ & $\Delta v^{S t}, \mathrm{~cm}^{-1}$ & $\lambda_{\text {las }}, \mathrm{nm}$ \\
\hline Rh6G/EtOH & 530 & 106 & 552 & 0.95 & 750 & 575 \\
Rh6G/DMSO & 539 & 100 & 564 & 0.97 & 820 & 585 \\
DCM/DMSO & 480 & 45 & 643 & 0.50 & 5280 & 654 \\
\hline
\end{tabular}

${ }^{*} \Delta v^{S t}$ - Stokes shift between the absorption and fluorescence maxima, $\lambda_{\text {las }}$ - central wavelength of lasing spectrum under laser pumping $\lambda_{\text {pump }}=508 \mathrm{~nm}$ in non-selective cavity (NSC), EtOH - ethanol.

ethanol solution of Rh6G, which quantum yield $q=0.95[12]$, was used as reference for determination of the quantum yield of it in DMSO. The quantum yield (for the room temperature) was calculated by formula [13]:

$$
q=q_{0} \cdot \frac{1-10^{-D_{0}}}{1-10^{-D}} \cdot \frac{S^{f l}}{S_{0}^{f l}} \cdot \frac{n^{2}}{n_{0}^{2}} .
$$

Here $q$ and $q_{0}$ - quantum yields of measured sample and reference, respectively; $D$ and $D_{0}$ - their optical densities at wavelength of extinction; $S^{f l}$ and $S_{0} f l-$ areas under curve of corrected fluorescent spectra; $n$ and $n_{0}$ - refraction coefficients of the solvents used (subscript "0" relates to reference, absence of index - to the measured sample). We used $n_{0}=1.36139$ for ethanol and $n=1.4795$ for DMSO [14] when calculated $q$. Having measured areas under curves of corrected fluorescent spectra and optical densities of the sample and reference at wavelength of extinction $\lambda_{e x}=$ $500 \mathrm{~nm}$ we have determined quantum yield of Rh6G in DMSO $q=0.97$.

The measured and calculated spectral parameters of selected laser dyes are adduced in Table 2. Note that the value of the Stokes shift $\Delta v^{S t}$ between the maxima of the absorption and fluorescence bands for DCM is six times more than for Rh6G.

We measured dependences of the output laser energy of one-component solutions of the dyes and their mixtures in DMSO on the concentration of the operating solution in the DL with NSC (Fig. 2) for determination of optimal dye concentrations $\left(C_{o p t}\right)$ in the tuned laser. Note the Rh6G solsolutions had lasing in the region of 580-590 $\mathrm{nm}$, the DCM ones - in the region of 650-660 nm, and their mixture $(239 \mu \mathrm{mol}$ Rh6G + $198 \mu \mathrm{mol} D C M$ ) - at $\lambda_{\text {las }}=628 \mathrm{~nm}$ (with half-width of spectrum $-6 \mathrm{~nm}$ ).

Having used obtained values of $C_{o p t}$ for the DL with diffraction grating we fulfilled continuous tuning laser emission for single solution of the dye mixture $239 \mu \mathrm{mol}$ Rh6G

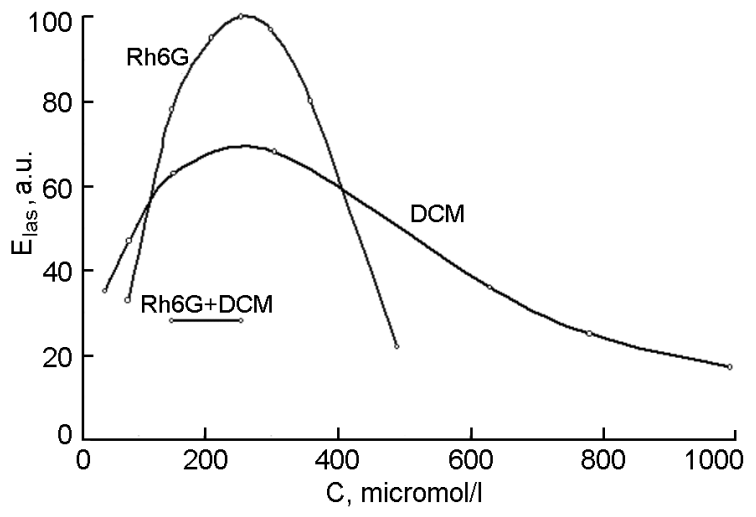

Fig. 2. Dependences of normalized laser energy of Rh6G and DCM dyes and their mixture in the NSC on concentration in DMSO.

$+198 \mu \mathrm{mol} D C M$ in DMSO in the region of $572-687 \mathrm{~nm}\left(\Delta \lambda_{\text {tun }}=115 \mathrm{~nm}\right.$, see Fig. 1$)$. This value is larger on $20 \mathrm{~nm}$ than result we obtained earlier [5] for mixture of the LD1 and DCM dyes, and on $15 \mathrm{~nm}$ is larger than one [15] obtained for the mixture of Rh6G and DCM in methanol.

\section{Conclusions}

Thus, the fulfilled studies of spectralfluorescence characteristics of the laser dyes and their energy parameters in non-selective cavity permitted essentially to expand the laser tuning range: all red region and abutted on it yellow range of the spectrum 572-687 $\mathrm{nm}$ were overlapped when single mixture of the tested couples of the dyes Rh6G and DCM in dimethylsulfoxide were used.

Examinations of the mixtures of two other couples of dyes: GD1 + DCM and GD2 + DCM (each of these individually produced efficient laser emission) have shown the following. For fabricating the active laser medium on mixture of dyes with wide-band laser spectrum tuning it is not sufficient to have the conditions that the selected couple of dyes in the operating solution have the absorption spectra close to pumping wave- 
length and the fluorescence ones have essential different values of Stokes shift. It is also necessary the absence of non-radiating losses in this mixture under interaction between the molecules of the dyes and their interaction with the solvent molecules.

Acknowledgment. I thank Dr. Yu.A. Gurkalenko for help in measuring fluorescence spectra of the laser dyes.

\section{References}

1. S.Chenais, S.Forget, Polymer Int., 61, 390 (2012).

2. J.Pierce, S.Lacey, R.Lopez et al., J.Laser Appl., 24, 032005 (2012).

3. M.S.Reddy, S.Kedia, R.Vijaya et al., IEEE Photonics J., 5, 4700409 (2013).

4. Ya.Wang, X.Shi, Ya.Sun et al., Opt.Lett., 39, 5 (2014).

5. V.V.Maslov, Functional Materials, 19, 226 (2012).
6. V.V.Maslov, N.Yu.Gorobets, A.V.Borisov, V.M.Nikitchenko, J.Appl.Spectr., 70, 794 (2003).

7. V.V.Maslov, Functional Materials, 13, 419 (2006).

8. V.V.Maslov, V.M.Nikitchenko, J.Appl.Spectr., 73, 454 (2006).

9. S.L.Bondarev, V.N.Knyukshto, V.I.Stepuro et al., J.Appl. Spectr., 71, 194 (2004).

10. J.M.Drake, M.L.Lesiecki, D.M.Camaioni, Chem. Phys. Lett., 113, 530 (1985).

11. C.A.Parker, Photoluminescence of Solutions, Elsevier, Amsterdam (1968).

12. R.F.Kubin, A.N.Fletcher, J.Luminescence, 27, 455 (1982).

13. G.A.Crosby, J.M.Demas, J.Phys.Chem., 75, 991 (1971).

14. Chemical Encyclopedia, Moscow (1990), Soviet Encyclopedia [in Russian].

15. S.Sinha, A.K.Ray, S.Kundu et al., Appl.Opt., 42, 7008 (2002). 